$\mathbb{T}$ periodica polytechnica

Civil Engineering

$55 / 1(2011) 63$ 671

doi: 10.3311/pp.ci.2011-1.08

web: http://www.pp.bme.hu/ci

(c) Periodica Polytechnica 2011

RESEARCH ARTICLE

\section{Affect of lightweight aggregate to early age cracking in concrete}

\author{
Olivér Fenyvesi
}

Received 2010-06-30, revised 2010-10-12, accepted 2010-10-15

\begin{abstract}
Concrete is often sensitive to cracking, which could be the result of early age shrinkage. Cracks can cause the corrosion of steel reinforcements and reduce the lifetime of concrete structures. Altogether crack tendency of concrete can be influenced by many parameters in the concrete mixture. Laboratory tests have been carried out according to the Austrian FRC technical specification, in particular with regard to early age shrinkage cracking. Seven different, commonly used lightweight aggregate types were used made from expanded glass, expanded clay, expanded perlite, polystyrene and crushed brick. In this paper, the relationship between the water absorption capacity and early age shrinkage cracking tendency was tested. In the laboratory compressive strength was also tested. In case of every aggregate type, the relationship between the absorbed water and cracking tendency was linear.
\end{abstract}

\section{Keywords}

Shrinkage $\cdot$ shrinkage cracking $\cdot$ early age shrinkage $\cdot$ internal curing $\cdot$ LWAC (Lightweight Aggregate Concrete)

\section{Acknowledgement}

The author expresses his thanks to the Duna-Dráva Cement Ltd. for providing the cement, to the Geofil Ltd. and the Biotech Hungária Ltd. for providing the expanded glass aggregates and to the LiaBau Ltd. for providing the expanded clay pellets necessary for the experiments. This work is connected to the scientific program of the "Development of quality-oriented and harmonized $R+D+I$ strategy and functional model at BME” project. This project is supported by the New Hungary Development Plan (Project ID: TÁMOP-4.2.1/B-09/1/KMR-2010-0002).

\section{Olivér Fenyvesi}

Department of Construction Materials and Engineering Geology, BME, H-1521, Budapest, Hungary

e-mail: fenyvesioliver@yahoo.com

\section{Introduction}

1.1 Early age shrinkage in concrete

In concrete, mortar and cement paste shrinkage takes place from the very beginning of the life of the material. This is caused by water movement in the porous and rigid body. During the hydration of cement, while the cement paste is plastic, it undergoes a volumetric contraction (autogenous shrinkage) whose magnitude is of the order of one per cent of the absolute volume of dry cement. However, the extent of hydration prior to setting is small, and once a certain stiffness of the system has developed, the contraction induced by the loss of water by hydration is greatly restrained [38]. Withdrawal of water from concrete, mortar or cement paste stored in unsaturated air causes drying shrinkage. A part of this drying shrinkage is irreversible and should be distinguished from the reversible moisture movement caused by alternating storage under wet and dry condition [24, 38].

Influencing factors of early age shrinkage in mix design:

- cement content of the paste

- specific surface area of cement

- fine aggregate content (under $0.125 \mathrm{~mm}$ particle size)

- specific surface area of fine aggregate

- water-cement ratio

- total aggregate content

- type of aggregate

- water absorption capacity/water content of aggregate

- applied admixtures

- compacting rate of paste

- porosity

- other added components e.g. fibres.

Shrinkage of concrete depends on the temperature of concrete and its surroundings, on relative humidity and on the velocity 
of air movement as well as the curing and composition of the concrete [38].

Free shrinkage of lightweight aggregate concrete (LWAC) made with fly ash aggregate was investigated by Kayali et al. [29]. They found that this type of aggregate reduces the elastic modulus of the concrete, so the same shrinking stress causes higher shrinkage in concrete. Merkallio et al. [35] have carried out experiments with LWAC made with crushed expanded clay aggregates. They measured the relative humidity in concrete, and separated the volume of mixing water into four groups: chemically bonded / absorbed into binder paste / absorbed into aggregate / evaporated. They concluded that when crushed expanded clay aggregate is used in concrete, very small water amounts are evaporated from the concretes, and large portion of the water is absorbed into the porous aggregate. Tang et al. [45] investigated LWAC made with polystyrene aggregates. They observed that the concrete density, strength and E-modulus decreased considerably with an increase of polystyrene aggregate content in the mix. The shrinkage rates of this concrete are greater than in normal weight concrete, because this aggregate does not absorb any water and the E-modulus of this concrete is lower, so there is no so called internal curing effect and the shrinkage strain is higher. Due to this, the reversible shrinkage was higher in this concrete as in normal weight concrete.

There are therefore two observed effects, the absorbed water causes lower shrinkage and the lower E-modulus causes higher shrinkage in LWAC. These two effects can be more pronounced if the porosity of the aggregate is higher, although the water absorbing capacity also depends on the open and closed porous ratio of the aggregate [37].

\subsection{Internal curing effect}

Kohno et al. [30] investigated three different types of artificial lightweight aggregates in 1999 with the main results being that autogenous shrinkage of LWAC is smaller than that of normal weight concrete and is related to the permeability and sorption capacity as well as the moisture content of aggregate. Elsharief et al. [14] analysed the microstructure of lightweight aggregate concretes. They found that around the lightweight aggregate (LWA) particles the porosity of mortar was smaller, due to the water absorption of the particles. This means that in the LWAC, the mortar also has higher strength and durability. Lura et al. [33] made a very good summary about this effect. Kato [28] has carried out some experiments with lightweight aggregates saturated with water, and took some scanning electron microscopic photos with fluorescence technique. The results are shown in Fig. 1. It was found that the porosity is lower around the water saturated aggregate particles, so the bond between the hardened cement paste and the particle is better.

Lo et al. also made photos with optical microscope to determinate the porosity near the aggregate surface in LWAC made with expanded clay aggregates. They found that higher water absorption capacity of LWA results from higher porosity in cement paste, although the tendency depends on the w/c ratio [31, 32]. The porosity of hardened cement paste depends also on compacting of concrete [46].

Akcay and Tasdemir investigated pre-soaked pumice LWAC, and their experimental results show that the use of lightweight coarse fraction is effective in mitigating autogenous deformation of concrete. The replacement of normal aggregate by LWA, even in as small a volume as $10 \%$, can decrease the linear autogenous deformation of concrete. In particular, the replacement of normal aggregate by fine fraction of LWA has been shown to be more effective in reducing the autogenous deformation compared to the use of the coarse fraction of LWAs [1.2].

Restrained autogenous shrinkage was also analysed in highstrength lightweight aggregate concrete by Bentur, et al. They found that autogenous shrinkage did not occur in the lightweight concrete with water saturated lightweight aggregate. However, expansion was observed in the concrete, as additional hydration reaction of cement took place due to the supply of internal water from the lightweight aggregate into the dense cement matrix. The partial replacement of normal-weight aggregate by water saturated lightweight aggregate was effective in eliminating all the autogenous shrinkage in high-strength concrete. The air dried lightweight aggregate was not sufficient to prevent autogenous shrinkage, although it did reduce its magnitude significantly (see Fig. 2). They observed the same effect in case of the stress development; it was reduced by the use of water saturated lightweight aggregate, or by partial replacement with water saturated lightweight aggregate [6].

Henkensiefken et al. investigated the internal curing effect in LWAC made by expanded shale aggregate. The speciality of these experiments was that fine aggregate was replaced with LWA. They found that addition of the lightweight fine aggregate increased the degree of hydration and produced a denser microstructure in hardened cement paste. This dense microstructure also results in a reduction in the water absorption capacity [26].

Bemtz and Snyder [7] have modelled in three dimensional models to find the optimal volume of lightweight fine aggregate content for the best internal curing effect in different conditions. Further information about internal curing in LWACs made with different types of lightweight aggregates are included in [3, 4,9 . 11, 13, 21, 34, 36, 47, 48].

Suzuki, Meddah and Sato have investigated high performance concrete (HPC) made with pre-saturated recycled waste porous ceramic coarse aggregate in the point of view internal curing. They have measured autogenous shrinkage and found, that using $40 \%$ of the aggregate volume, the LWA results in no autogenous shrinkage. The incorporation of the aggregate does not reduce the strength of the concrete and leads to a significant decrease of the internal capillary tension in the cement paste, which is proportional to the autogenous shrinkage decrease [43].

Sahmaran et al. analysed the internal curing of engineered cementitious composites (ECC) made with saturated fine LWA 


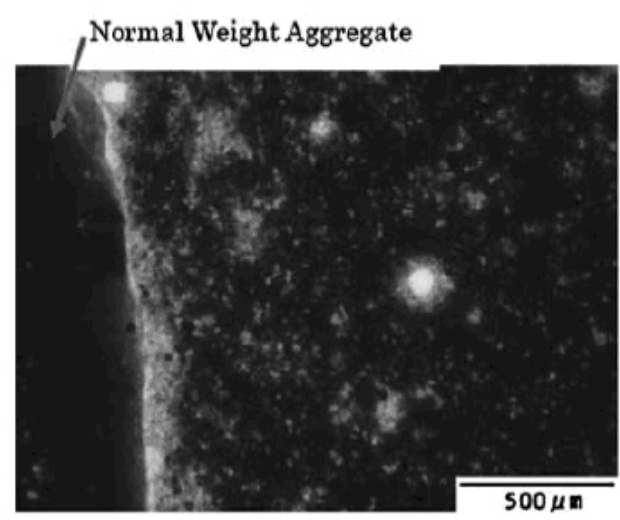

(a) NWA

Fig. 1. Fluorescence microscope images of interfacial transition zone between cement paste and aggregate particles (normal weight aggregate left,

(volcanic pumice sand). ECC is a micromechanically-based high performance, fibre reinforced cementitious composite. They have found that LWA was very effective in reducing the autogenous shrinkage and drying shrinkage of ECC [39].

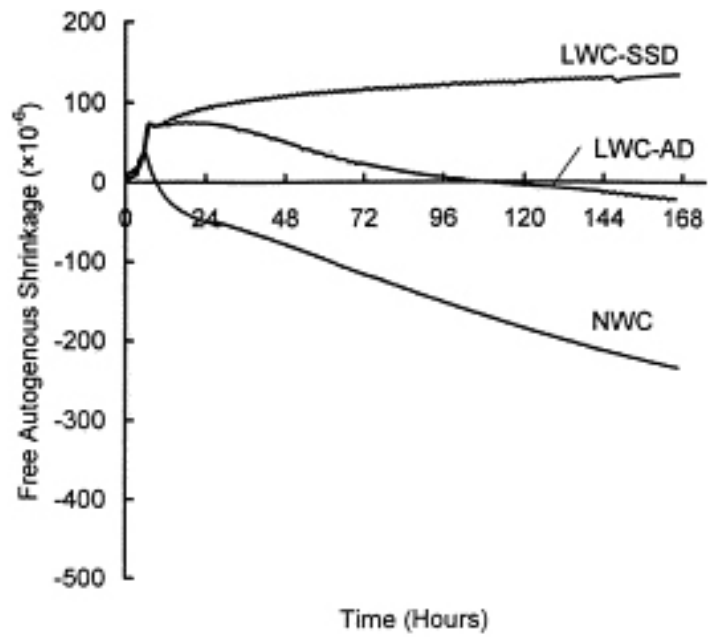

Fig. 2. Comparison of free autogenous shrinkage of lightweight and normalweight concretes, in the horizontal axis time is indicated (LWC: lightweight concrete; NWC: normal-weight concrete; SSD: saturated-surface dry aggregate; $\mathrm{AD}$ : air dry aggregate). 6

\subsection{Early age shrinkage cracking}

The importance of shrinkage in structures is largely related to cracking [44]. Time has a two-fold effect from this point of view: the strength increases, thereby reducing the cracking tendency, but on the other hand, the stress induced by shrinkage also increases. If stress reaches the tensile strength of concrete, cracks appear on the structure or specimen (Fig. 3) [8, 38].

Henkensiefken et al. [25] have also investigated the shrinkage cracking of concrete with the fine fraction of expanded shale lightweight aggregate, and found that specimens with larger volume of LWA showed greater reduction in both the rate of shrinkage and the volume of autogenous shrinkage. They have measured cracking time and strain and found that due to the internal curing effect cracking time is prolonged. Cusson and

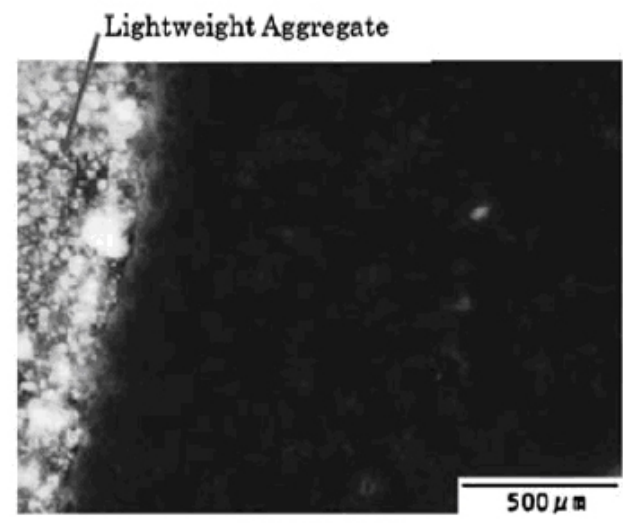

(b) LWA(SSD)

lightweight aggregate right). The darker interfacial transition zone in the right picture indicates lower porosity thus better bond [28]

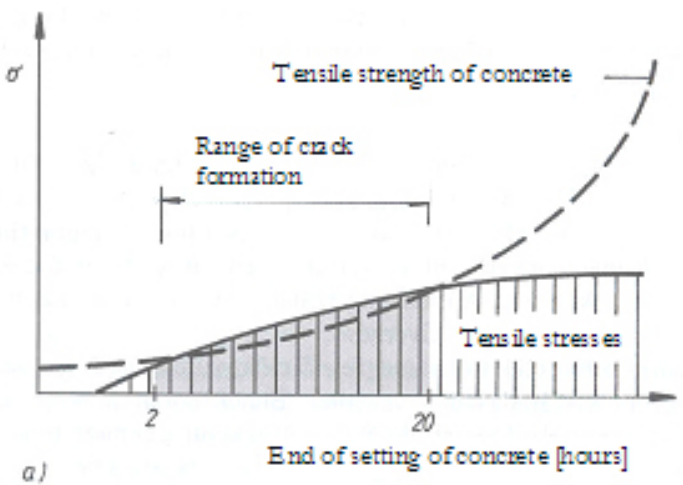

Fig. 3. Comparison of tensile strength and tensile stresses caused by early age shrinkage in concrete, in the horizontal axis time is indicated [8,38]

Hoogeveen [10] have carried out some experiments with high performance concretes (HPC) made with pre-soaked expanded shale lightweight sand. In these experiments they could make a mixture which has no autogenous shrinkage, and maintain the critical tensile stress well under the tensile strength due to the internal curing effect. They measured autogenous swelling within the first day for the specimens using pre-soaked LWA.

To study crack tendency of different cement types Balázs et al. [5] carried out ring tests, where the time of cracking was measured. Restrained shrinkage was also studied by Salah and Lange in 2001 [40] and also by Shah in fibre reinforced concretes (FRC) in 2006 [42].

Considering structural lightweight concrete made with coldbonded fly ash aggregates, Gesoglu et al. [22] investigated the crack tendency by ring tests. They evaluated crack width-time curves and found that the concretes with $60 \mathrm{~V} / \mathrm{V} \%$ lightweight aggregate content cracked 1 or 2 days later than their counterparts with lower lightweight coarse aggregate content. Later they investigated four different types of cold-bonded fly ash aggregates with two different $\mathrm{w} / \mathrm{c}$ ratios, and found that the shrinkage cracking performance of the concretes was affected by the lightweight aggregate type. Due to the lower free shrinkage and higher tensile strength, the cracking age was remarkably ex- 
tended and the crack width was less for concretes with stronger (higher crush resistance) aggregates [23].

Recently an another test method has been used to evaluate restrained early age shrinkage according to the Austrian fibre-concrete technical specification described in Faserbeton Richtlinie $(2002,2008)$ [16, 17]. This method was used by Józsa et al. in 2005 [27], and by Schmidt in 2005 [41] and also in present experiments. This method was also followed to measure early age shrinkage cracks of lightweight aggregate concrete by Fenyvesi in 2006 and in FRC in 2010 [18,19].

\section{Experimental study}

\subsection{Research goals}

If the strength and density properties of lightweight aggregate concretes are analyzed, it can be found that at the higher porosity of the aggregate the lower strength and body density is achieved [20]. Recently the durability performance of concretes (including lightweight aggregate concretes) became more and more important. Cracking tendency caused by early age shrinkage is one of the most important influencing parameters of durability of concretes. In case of exposed concretes water and other corrosive materials can penetrate into the concrete trough the cracks and may damage steel reinforcing bars and the concrete itself too. In case of fair faced concretes and watertight concretes avoiding cracks is a general requirement.

In practice, the most important question of the lightweight concrete mix design is the choice of aggregate type. The previous studies investigated only one type of LWA and did not compare different aggregate types. The main goal of present research was to compare the early age shrinkage cracking tendency of different commonly used LWAs, and to find an easy measurable LWA parameter on which this property depends.

\subsection{Testing crack tendency according to the Austrian fibre- concrete technical specification [16.17]}

The Austrian technical specification was made to give a detailed test method to determine the effectiveness of fibres in concrete against early age shrinkage crack tendency (caused by autogenous and drying shrinkage) [16,17]. Crack tendency can be influenced by many parameters of concrete mix design, not only fibre content. In our researches the method was used to indicate crack tendency of LWAC without fibres.

The technical specification gives a mixture recipe which is very sensitive to early age shrinkage cracking. This mixture contains a high volume $\left(500 \mathrm{~kg} / \mathrm{m}^{3}\right)$ of fine particle size under $0.125 \mathrm{~mm}$ (cement is $360 \mathrm{~kg} / \mathrm{m}^{3}$ from it). The water-cement ratio is 0.61 .

The technical specification describes a test method for which special ring specimens are needed. The outer diameter of the ring is $60 \mathrm{~cm}$, the inner is $30 \mathrm{~cm}$. The height of the ring is $4 \mathrm{~cm}$. To the inner side of the outer formwork steel plates are welded, to increase crack tendency of the specimen (Fig. 4). The formworks are fixed in a wind tunnel (Fig. 5), with movable upper covering. Just after mixing, fresh concrete must be put into in the fixed formworks and compacted. The experiment requires that the wind tunnel is switched on two hours after concrete mixing. The experiment goes on for five hours, and has to be carried out in a climate of $65 \%$ relative humidity and $20{ }^{\circ} \mathrm{C}$. The Department of Construction Materials and Engineering Geology of Budapest University of Technology and Economics is equipped to carry out experiments which need these conditions in a climatic room with an air conditioner and a moisturizing device. In present experiments this method was used to determine the influence the type of different of lightweight aggregates to the early age shrinkage crack tendency of concretes.

\subsection{Concrete mixtures}

All the mixtures contained $66 \mathrm{~V} / \mathrm{V} \%$ fine and coarse aggregate and $140 \mathrm{~kg} / \mathrm{m}^{3}$ limestone dust was added to improve crack tendency of the concrete. The pure Portland cement is the least favorable with regard to early age shrinkage cracks. That was the reason for applying CEM I 42.5 N (normal) Portland cement $\left(360 \mathrm{~kg} / \mathrm{m}^{3}\right.$ in every mixture) in our experiments. The watercement ratio was relatively high: 0.61 to enhance early age shrinkage in the concrete. Plasticizer admixture was applied to set up to the same level of consistency in the case of every mixture (spread 500 to $550 \mathrm{~mm}$ ).

The variable parameter was the type of coarse aggregates $(4 / 8$ fraction). The fine (0/4) fraction was quartz sand in every mixture. Seven types of lightweight aggregates were used, three of them were made from glass, one was expanded perlite one was the most commonly used expanded clay, one was polystyrene, and one was crushed clay brick. To compare the results a reference mixture with normal weight quartz sand and gravel was made.

\subsection{Applied test methods}

Consistency of the fresh concrete was measured by flow table test, directly after the mixing according to EN 206-1 [15]. The density of fresh concrete was measured by weighing both empty and filled formworks. Compressive strength of concrete was tested on standard cube specimens (with dimensions $150 \times$ $150 \times 150 \mathrm{~mm}$ ) at the age of 28 days according to EN 206-1 [15]. These measurements have been made to check the main parameters of concrete.

For early age shrinkage tests, ring specimens were prepared according to the instructions of the Austrian technical specification [16, 17] (Tab. 1). Four ring specimens for every mixture were prepared. Two hours after mixing, the specimens were placed in a wind tunnel for five hours (Figs. 6 and 7). After keeping them for five hours in the wind tunnel, the lengths and width of every crack were registered and summarized, which indicates the early age shrinkage cracking tendency of the mixture (Fig.8). Beside testing according to the Austrian technical specification [16, 17] the ring specimens were stored in a tumblerdrier for two further days at a temperature $60{ }^{\circ} \mathrm{C}$ to achieve im- 


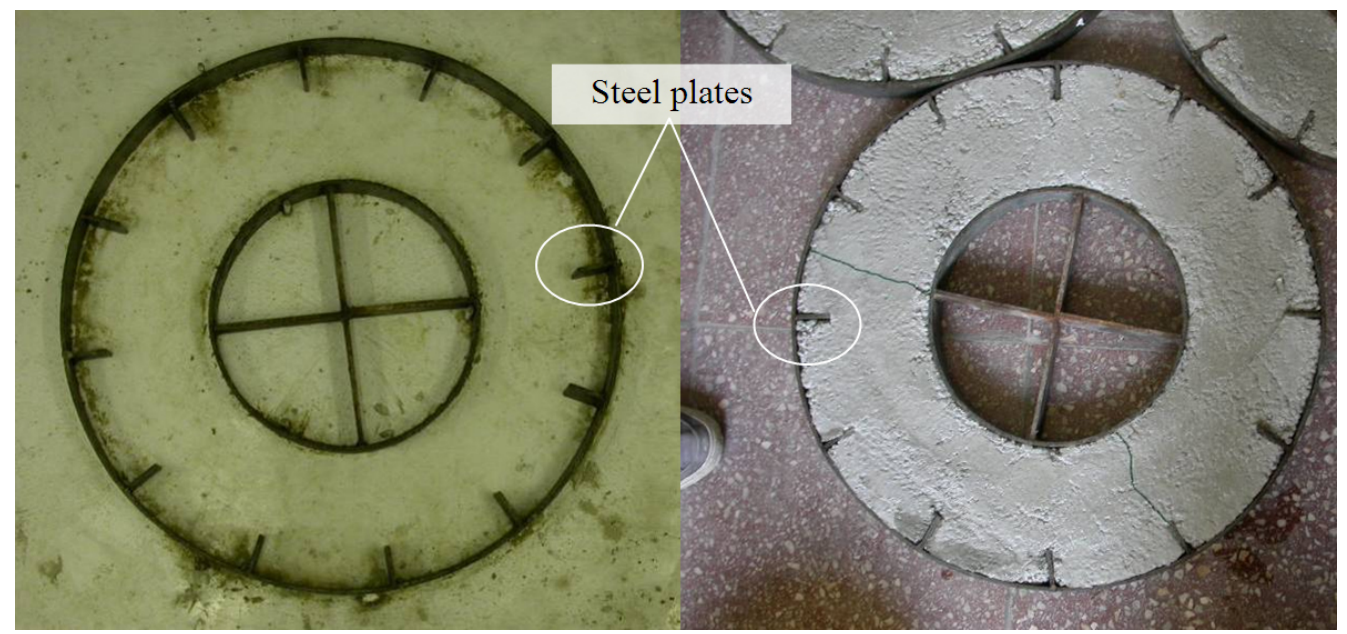

Fig. 4. Empty (left) and filled (right) formworks for measuring crack tendency according to the Austrian fibre-concrete technical specification [16 17] 19 27]

proved drying, after which additional cracks were registered on the specimens (Fig.9).

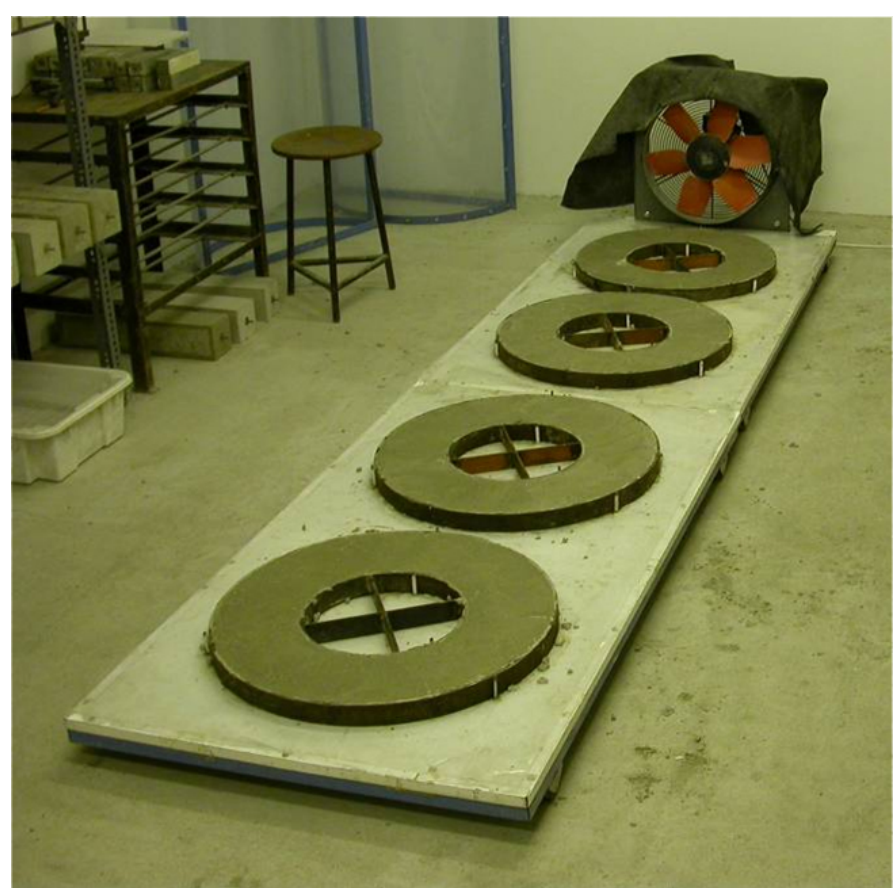

Fig. 5. Empty wind tunnel with ring specimens according to the Austrian fibre-concrete technical specification [16 17]

To evaluate early age shrinkage crack tendency of every mixture the length of every crack for each specimen was summarized. The average of the summarized crack length of the four ring specimens indicates the crack tendency of mixtures. A method is proposed for this evaluation whereby the crack length is multiplied with the crack width and these values are added to each other. To evaluate the effectiveness of the types of aggregates, a reference mixture with normal aggregate was prepared too.

\section{Experimental results}

Almost all the references show if the lightweight aggregate content is increased in concrete the shrinkage of concrete is decreasing, due to the internal curing effect. But if the lightweight

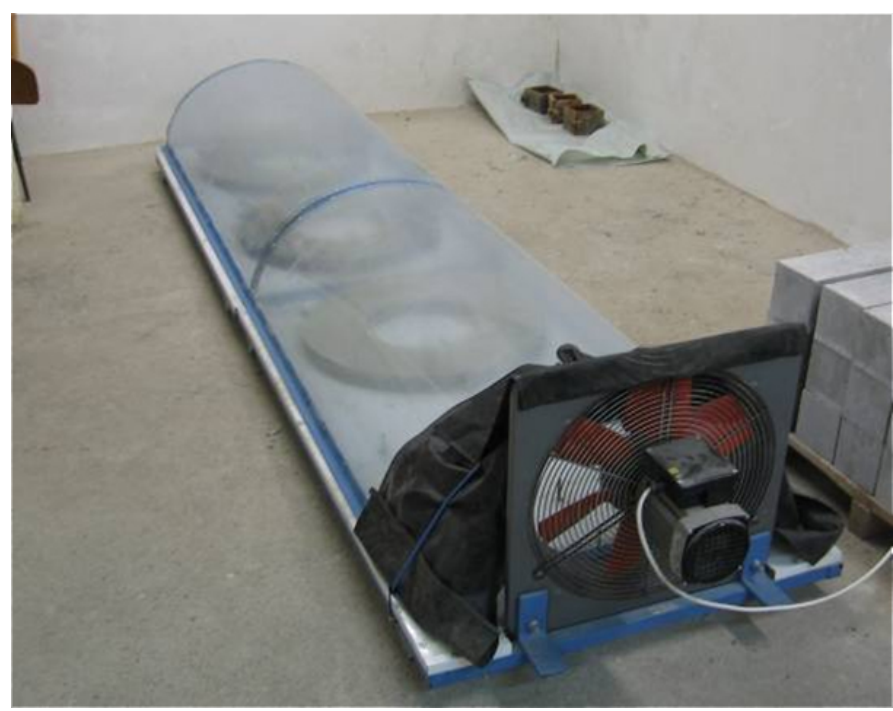

Fig. 6. Wind tunnel with ring specimens according to the Austrian fibre-

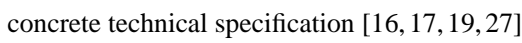

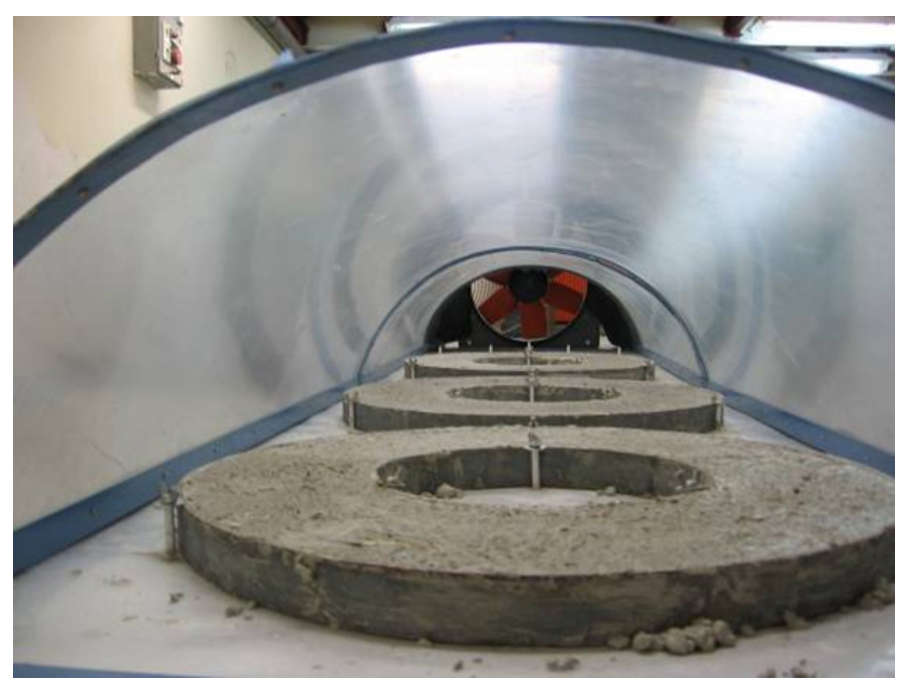

Fig. 7. Wind tunnel with ring specimens according to the Austrian fibre-

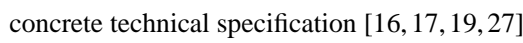


Tab. 1. Applied test methods

\begin{tabular}{cccc}
\hline Measured property & Type of specimen & Duration/Age & Method \\
\hline Water absorption capacity & Aggregate bulk & 0,5 and 24 hours & Mass weighting \\
\hline Aggregate body density & Aggregate bulk & - & Mass weighting \\
\hline Fresh concrete body density & Cube $150 \times 150 \times 150 \mathrm{~mm}$ & 15 minutes & Mass weighting \\
\hline Consistency & - & 10 minutes & Flow table test \\
\hline Compressive strength & Cube $150 \times 150 \times 150 \mathrm{~mm}$ & 28 days & Compression test \\
\hline Early age crack tendency & Ring $ø 600 / 300 \times 40 \mathrm{~mm}$ & 5 hours & Wind drying \\
\hline Early age crack tendency & Ring $ø 600 / 300 \times 40 \mathrm{~mm}$ & 2 days & Ordinary drying \\
\hline
\end{tabular}

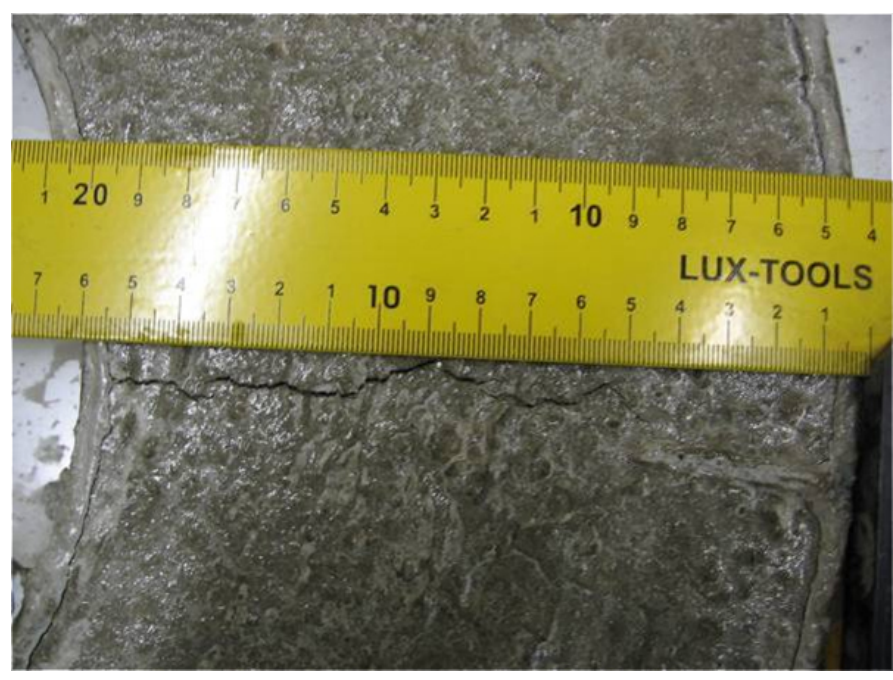

Fig. 8. Measuring crack length on a ring specimen after testing [19 27]

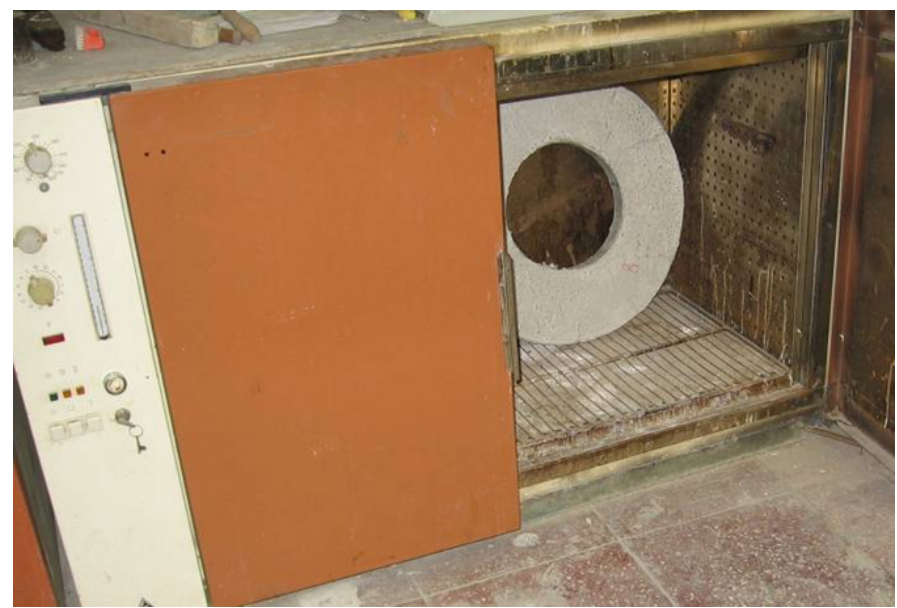

Fig. 9. Testing ring specimens in tumbler dryer aggregate has no water absorption capacity, which depends on the volume of open pore - closed pore rate of the aggregate, there is no decrease of shrinkage. So that connection between crack tendency parameters and water absorption capacity of the aggregate itself was analyzed.

In Fig. 10 the relationship between water absorption at 24 hours age and summarized crack length can be seen after the two applied crack tendency test (wind tunnel and tumbler dryer).

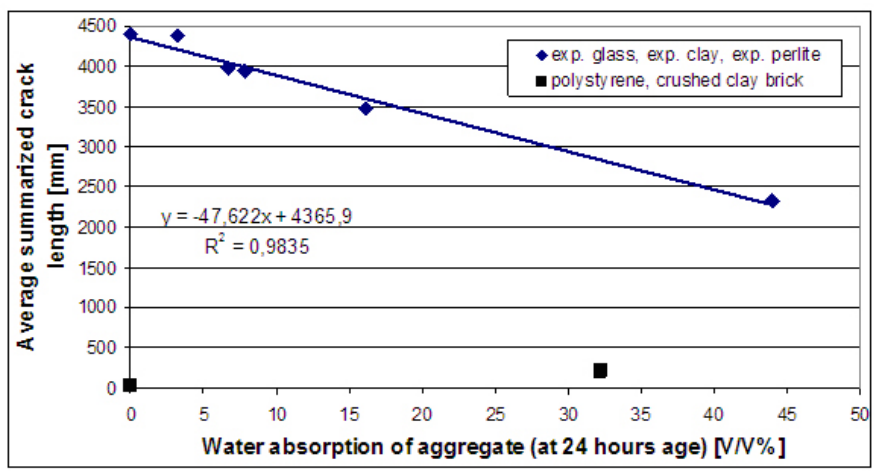

Fig. 10. Relationship between water absorption at 24 hours age and summarized crack length after the two (wind tunnel and tumbler dryer) test

It can be seen that the relationship is linear, so that the higher the open porosity in the lightweight aggregate, the lower the early age crack tendency of the lightweight aggregate concrete, in case of expanded glass, exp. clay and exp. perlite aggregates.

Polystyrene and the crushed clay brick are not in the curve. Polystyrene has such a low E-modulus that the tensile stresses caused by the shrinkage strain are so low, as to not reach the tensile strength of the concrete. This explains why only a few cracks could be found on these specimens. Crushed clay brick results in less cracks on concrete because it absorbs water very fast, and take it back to the concrete very slowly. This results fast consistency reducing in the early age of concrete, so the crack tendency will be definitely lower as in case of the other types of LWA which absorb water slowly.

If each crack length was multiplied with the crack width almost the same result can be found. This method can be necessary because it can be realized that in some ring specimens there could be found some wide cracks (0.4-0.5 mm crack width) and in other rings, made with other mixture parameters there were 
only narrow cracks ( $0.05 \mathrm{~mm}$ crack width). So it can be important to make a difference between these cracks, and the multiplication is usable for this. This relationship can be seen on Fig. 11

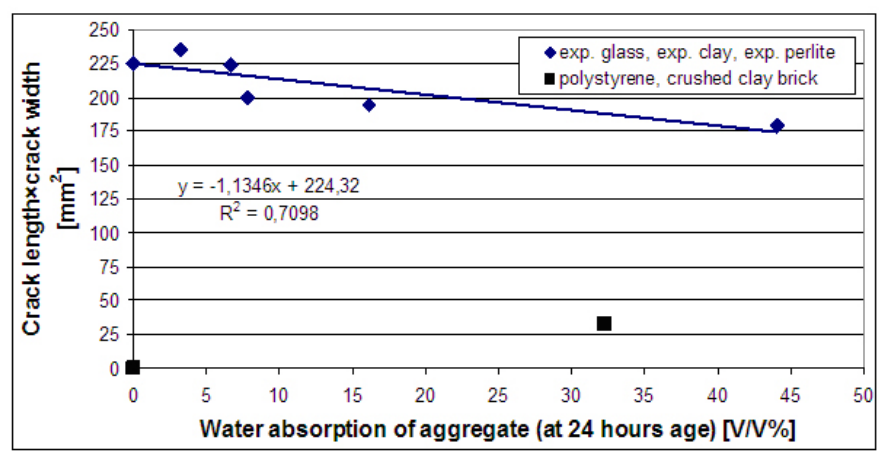

Fig. 11. Relationship between water absorption at 24 hours age and summarized crack length multiplied with crack width after the two (wind tunnel and tumbler dryer) test

The relationship here is linear too. It can be determined that the result is the same in case of the two used calculation method.

After the wind tunnel test the cracks were measured too, so it can be represent the results of these experiments too (Fig. 12).

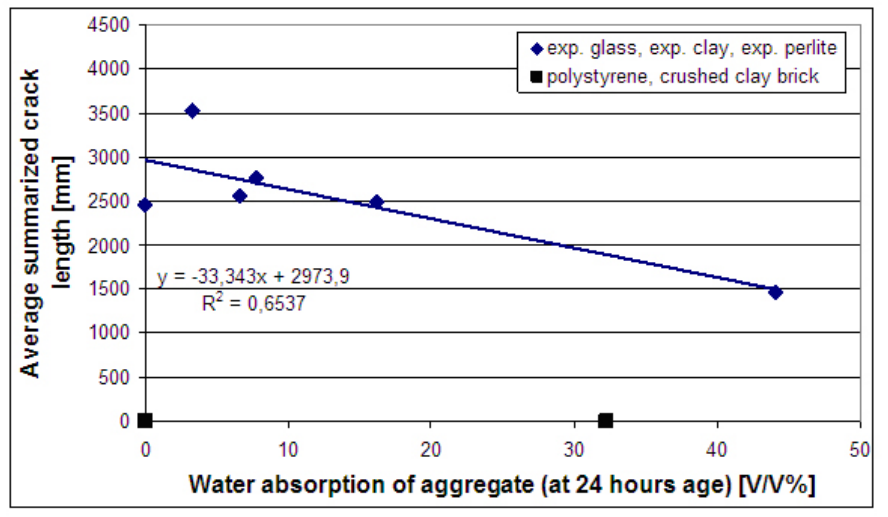

Fig. 12. Relationship between water absorption at 24 hours age and summarized crack length after the wind tunnel test

The crack length multiplied with crack width values of the ring specimens of this experiment was calculated too. The results are shown on the Fig. 13

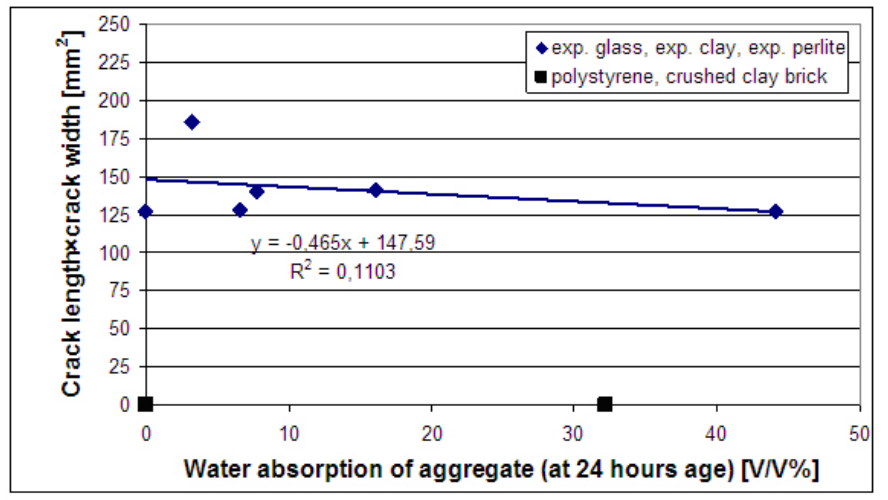

Fig. 13. Relationship between water absorption at 24 hours age and summarized crack length multiplied with crack width after the wind tunnel
We can see that the correspondence of the values after the wind tunnel test is the same as after the two tests, but the deviation of the measurements is much higher. So it can be concluded, that testing with the two methods results in more precise crack tendency values. It is therefore highly recommended to complement the test method of the Austrian fibre-concrete specification with further drying test methods.

According to the evaluation of Austrian fibre-concrete specification a fibre type is effective if the summarized crack length reduced to $20 \%$ as in the reference mix (without fibres). We can use therefore LWA as fibres in concrete to reduce crack length in concrete. Only the crushed clay brick and the polystyrene aggregate were as effective as fibres in concrete and reduced summarized crack length under $20 \%$ as in the reference mix made with normal weight aggregate, but every type of aggregate which can absorb water reduces crack tendency of concrete.

The compressive strength and body density values of the tested concretes included in Tab. 2 .

\section{Conclusions}

In this paper early age shrinking crack tendency of lightweight aggregates were investigated. According to the references, there are three different effects in this case:

- internal curing caused by the water absorption of lightweight aggregate during hydration of the hardened cement paste reduces shrinkage in concrete

- the LWAC has lower E-modulus, so the stress according to the same deformation level is lower

- the porosity of the hardened cement paste close to the lightweight aggregate particles is lower than in normal weight concretes, so the tensile strength of hardened cement paste and the bond between aggregate and hardened cement paste are higher there. (Although not only the porosity of the cement matrix but also the surface roughness of the aggregate is also important to describe the bond between the materials).

Measurements have been carried out with ring test according to the Austrian fibre-concrete specification complemented with further drying test in ordinary tumbler dryer for two days on the same specimens. It was used to determinate crack tendency of concretes made with different LWA types. After both tests all cracks appeared on the specimens (length and width) were measured.

After evaluating the measurement results it can be concluded that:

1 Two evaluating methods can be used for the applied tests, we can summarize crack length of all specimens and the average value of minimum four specimens can be compared, or we can multiply the crack length with crack width and after this summarize the results of each specimen and the average value of minimum four specimens can be compared. 
Tab. 2. Compressive strength and body density of the tested concretes

\begin{tabular}{cccc}
\hline & & \multicolumn{2}{c}{ Average concrete body density } \\
\cline { 3 - 4 } Type of aggregate & Average compressive strength & Fresh & $\begin{array}{c}\text { Saturated } \\
\text { at 28 days age }\end{array}$ \\
\cline { 3 - 4 } & $\mathrm{N} / \mathrm{mm}^{2}$ & $\mathrm{~kg} / \mathrm{m}^{3}$ & $\mathrm{~kg} / \mathrm{m}^{3}$ \\
\hline Nat. quartz gravel & 44,4 & 2331 & 2365 \\
\hline Exp. glass 1 & 15,6 & 1545 & 1647 \\
\hline Exp. clay & 35,5 & 1895 & 1907 \\
\hline Crushed clay brick & 40,8 & 2115 & 2109 \\
\hline Exp. glass 2 & 22,4 & 1549 & 1568 \\
\hline Exp. glass 3 & 31,5 & 1855 & 1869 \\
\hline Polystyrene & 7,2 & 1358 & 1378 \\
\hline Exp. perlite & 16,4 & 1762 & 1763 \\
\hline
\end{tabular}

2 The test method of the Austrian fibre-concrete technical specification can be used for evaluating early age crack tendency but results in higher distribution compared with the equivalent test method.

3 There is a connection between the early age crack tendency of LWAC and the water absorption capacity of LWA.

4 This relationship between early age crack tendency of LWAC and water absorption capacity of lightweight aggregates is linear, if the aggregate absorb water slowly enough. If water absorption is fast the crack tendency is lower.

5 The concretes with lower E-modulus have lower crack tendency due to the lower tensile stresses in concrete induced by the same strains.

There are only few data in the technical literature in which different aggregate types were compared from the point of early age shrinkage cracking tendency and mostly only shrinkage itself were investigated (and cracking tendency not). In most cases only one aggregate type was compared with normal aggregates.

Water absorption can be measured in a simple way and according to the experimental results it indicates cracking tendency of LWAC. Therefore, in practice the results of present paper can help to choose LWA type for LWAC mix design if early age cracks have to be avoided (e.g. in case of exposed concretes, fair faced concretes and watertight concretes). According to present results the lifetime of structures made with LWAC can be extended.

Further investigations are needed to find the optimal test method and evaluation for indicating crack tendency however the applied method is usable. Also further tests have to be made with other LWAs and other particle sizes in concrete.

\section{References}

1 Akcay B, Tasdemir M A, Internal curing of mortars by lightweight aggregates and its effects on hydration, Canadian Journal of Civil Engineering 35 (2008), no. 11, 1276-1284, DOI 10.1139/L08-078.

2 _ Optimisation of using lightweight aggregates in mitigating autogenous deformation of concrete, Construction and Building Materials 23 (2009), no. 1, 353-363, DOI 10.1016/j.conbuildmat.2007.11.015.

3 Balaguru P, Dipsia M G, Properties of fiber-reinforced high-strength semilightweight concrete, Aci Materials Journal 90 (1993), no. 5, 399-405.

4 Balaguru P, Foden A, Properties of fiber reinforced structural lightweight concrete, Aci Structural Journal 93 (1996), no. 1, 62-78.

5 Balázs Gy, Borján J, Cary S J, Liptay A, Zimonyi Gy, Crack tendency of cement (A cement repedésérzékenysége), Budapest Univerity of Technology and Economics, 1979. ISSN 0324-3575.

6 Bentur A, Igarashi S, Kovler K, Prevention of autogenous shrinkage in high-strength concrete by internal curing using wet lightweight aggregates, Cement and Concrete Research 31 (2001), no. 11, 1587-1591.

7 Bentz D, Snyder K, Protected paste volume in concrete - Extension to internal curing using saturated lightweight fine aggregate, Cement and Concrete Research 29 (1999), no. 11, 1863-1867.

8 CEB No. 183 “Durable Concrete Structures” - Design Guide, CEB, 1992. ISBN 978-0-7277-1620-0.

9 Cleary J, Delatte N, Implementation of Internal Curing in Transportation Concrete, Transportation Research Record , posted on 2008, no. 2070, 1-7, DOI 10.3141/2070-01, (to appear in print).

10 Cusson D, Hoogeveen T, Internal curing of high-performance concrete with pre-soaked fine lightweight aggregate for prevention of autogenous shrinkage cracking, Cement and Concrete Research 38 (2008), no. 6, 757 765, DOI 10.1016/j.cemconres.2008.02.001.

11 Davraz M, Gunduz L, The Effect of Using Saturated Lightweight Aggregate on Shrinkage and Hydration Degree of High Performance Concrete, Science and Engineering of Composite Materials 16 (2009), no. 4, 225-234.

12 Ding Q J, Tian Y G, Wang F Z, Zhang F, Hu S, Autogenous shrinkage of high strength lightweight aggregate concrete, Journal of Wuhan University of Technology-Materials Science Edition 20 (2005), no. 4, 123-125.

13 Duran-Herrera A, Aitcin P C, Petrov N, Effect of saturated lightweight sand substitution on shrinkage in $0.35 \mathrm{w} / \mathrm{b}$ concrete, Aci Materials Journal 104 (2007), no. 1, 48-52.

14 Elsharief A, Cohen M D, Olek J, Influence of lightweight aggregate on the microstructure and durability of mortar, Cement and Concrete Research $\mathbf{3 5}$ (2005), no. 7, 1368-1376. 
15 ENÂ 206-1:2000 Concrete - Part 1: Specification, performance, production and conformity, European Code, 2000.

16 Austrian fibre-concrete technical specification (in German) Östereichische Vereinigung für Beton- und Bautechnik, Austrian Technical Specification, 2002.

17 Austrian fibre-concrete technical specification (in German) Östereichische Vereinigung für Beton- und Bautechnik, Austrian Technical Specification, 2008.

18 Fenyvesi O, Early Age Shrinkage Cracking of Fibre Reinforced Lightweight Aggregate Concrete, 6th International PhD Symposium in Civil Engineering (Zürich, 2006), 2006, pp. 1-8.

19 Józsa Zs, Fenyvesi O, Early age shrinkage cracking of fibre reinforced concrete, Concrete Structures 11 (2010), no. 1, 61-66.

20 fib Bulletin 8 Lightweight Aggregate Concrete, Recommended extensions to Model Code 90; Case studies, FIB, 2000.

21 Fujiwara T, Effect of aggregate on drying shrinkage of concrete, Journal of Advanced Concrete Technology 6 (2008), no. 1, 31-44.

22 Gesoglu M, Ozturan T, Guneyisi E, Shrinkage cracking of lightweight concrete made with cold-bonded fly ash aggregates, Cement and Concrete Research 34 (2004), no. 7, 1121-1130, DOI 10.1016/j.cemconres.2003.11.024.

$23 \ldots$ _Effects of cold-bonded fly ash aggregate properties on the shrinkage cracking of lightweight concretes, Cement \& Concrete Composites 28 (2006), no. 7, 598-605, DOI 10.1016/j.cemconcomp.2006.04.002.

24 Grube H, Definitions of different types of shrinkage in German (Definition der verschiedenen Schwindarten), Beton 53 (2003), no. 12, 598-605.

25 Henkensiefken R, Bentz D, Nantung T, Weiss J, Volume change and cracking in internally cured mixtures made with saturated lightweight aggregate under sealed and unsealed conditions, Cement \& Concrete Composites 31 (2009), no. 7, 427-437, DOI 10.1016/j.cemconcomp.2009.04.003.

26 Henkensiefken R, Castro J, Bentz D, Nantung T, Weiss J, Water $a b$ sorption in internally cured mortar made with water-filled lightweight aggregate, Cement and Concrete Research 39 (2009), no. 10, 883-892, DOI 10.1016/j.cemconres.2009.06.009.

27 Józsa Zs, Djember Cs, Für Kovács I, Seidl Á, Use of Glass and Synthetic Fibres Preventing Early Age Cracking of Normal and Lightweight Concrete, 1st Central European Congress on Concrete Engineering (Graz, 2006), 2006, pp. $125-130$.

28 Kato T, Effects of internal curing on the formation of microstructure in the interfacial zone between lightweight aggregate and cement paste matrix, Kanazawa University, Kanazawa, Japan, 2004. M. Eng. Thesis

29 Kayali O, Haque M N, Zhu B, Drying shrinkage of fibre-reinforced lightweight aggregate concrete containing fly ash, Cement and Concrete Research 29 (1999), no. 11, 1835-1840.

30 Kohno K, Okamoto T, Isikawa Y, Sibata T, Mori H, Effects of artificial lightweight aggregate on autogenous shrinkage of concrete, Cement and Concrete Research 29 (1999), no. 4, 611-614.

31 Lo T Y, Cui H Z, Tang W C, Leung W M, The effect of aggregate absorption on pore area at interfacial zone of lightweight concrete, Construction and Building Materials 22 (2008), no. 4, 623-628, DOI 10.1016/j.conbuildmat.2006.10.011.

32 Lo T Y, Sham F C, Cui H Z, Tang W C P, Study of short term shrinkage and creep of lightweight concrete, Materials Research Innovations 12 (2008), no. 3, 151-154, DOI 10.1179/143307508X333622.

33 Lura P, Jensen O M, Igarashi S I, Experimental observation of internal water curing of concrete, Materials and Structures 40 (2007), no. 2, 211220, DOI 10.1617/s11527-006-9132-x.

34 Lydon F D, Effect of coarse aggregate and water/cement ratio on intrinsic permeability of concrete subject to drying, Cement and Concrete Research 25 (1995), no. 8, 1737-1746.

35 Merikallio T, Mannonen R, Penttala V, Drying of lightweight concrete produced from crushed expanded clay aggregates, Cement and Concrete Research 26 (1996), no. 9, 1423-1433.

36 Neithalath N, Evaluating the short-and long-term moisture transport phenomena in lightweight aggregate concretes, Magazine of Concrete Research 59 (2007), no. 6, 435-445.

37 Nemes R, Józsa Zs, Strength of lightweight glass aggregate concrete, Journal of Materials in Civil Engineering 18 (2006), no. 5, 710-714, DOI 10.1061/(ASCE)0899-1561(2006)18:5(710).

38 Neville A M, Properties of concrete, Longman Group Limited, London, 1995. ISBN: 0-582-23070-5.

39 Sahmaran M, Lachemi M, Hossain K M A, Li V C, Internal curing of engineered cementitious composites for prevention of early age autogenous shrinkage cracking, Cement and Concrete Research 39 (2009), no. 10, 893901, DOI 10.1016/j.cemconres.2009.07.006.

40 Salah A, Lange D A, Creep, Shrinkage and Cracking of Restrained Concrete at Early Age, ACI Materials Journal 98 (2001), no. 4, 323-331.

41 Baumbach Metall GmbH Product informations for PP fibers, (in German), Baumbach Metall GmbH, 2005.

42 Shah H R, Weiss J, Quantifying shrinkage cracking in fiber reinforced concrete using the ring test, Materials and Structures 39 (2006), no. 9, 887-899, DOI 10.1617/s11527-006-9089-9.

43 Suzuki M, Meddah M S, Sato R, Use of porous ceramic waste aggregates for internal curing of high-performance concrete, Cement and Concrete Research 39 (2009), no. 5, 373-381, DOI 10.1016/j.cemconres.2009.01.007.

44 Szabó K Zs, Balázs L Gy, Near surface mounted FRP reinforcement for strengthening of concrete structures, Periodica Polytechnica 51 (2007), no. 1, 33-38, DOI 10.3311/pp.ci.2007-1.05.

45 Tang W C, Lo Y, Nadeem A, Mechanical and drying shrinkage properties of structural-graded polystyrene aggregate concrete, $\mathrm{Ce}-$ ment \& Concrete Composites 30 (2008), no. 5, 403-409, DOI 10.1016/j.cemconcomp.2008.01.002.

46 Völgyi I, Farkas Gy, Nehme S G, Concrete strength tendency in the wall of cylindrical spun-cast concrete elements, Periodica Polytechnica 54 (2010), no. 1, 23-30, DOI 10.3311/pp.ci.2010-1.03.

47 Ye J J, Hu S G, Wang F Z, Zhou Y F, Liu Z C, Effect of pre-wetted lightweight aggregate on internal relative humidity and autogenous shrinkage of concrete, Journal of Wuhan University of Technology-Materials Science Edition 21 (2006), no. 1, 134-137.

48 Zhutovsky S, Kovler K, Bentur A, Efficiency of lightweight aggregates for internal curing of high strength concrete to eliminate autogenous shrinkage, Materials and Structures 35 (2002), no. 246, 97-101. 